


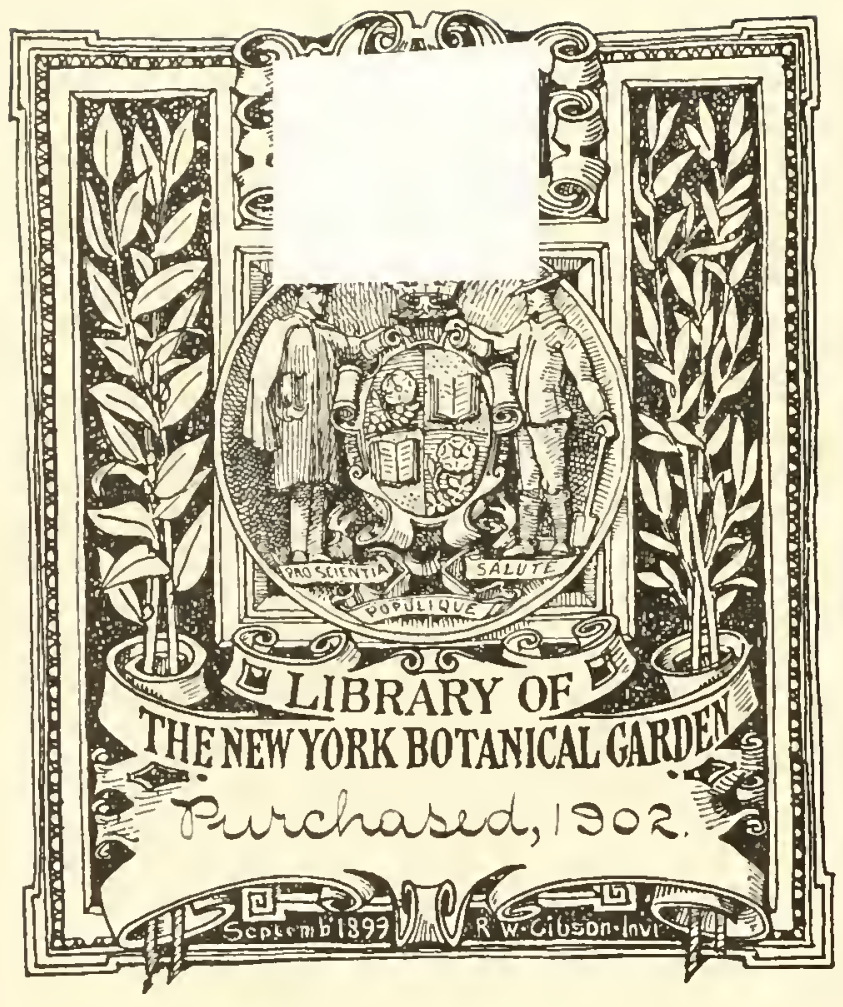



TRANSACTLOS

OF TIL

\section{IROYAL NOCIFIY OF EDINBURGH.}

VOL. XXXY.-PART I., NOs. 5 ANT 6.

ON NeUROP'TERIS PLICATA, Sternberg, AND

NEUROPTERIS RECTINERVIS, KIDSTON, n. sp.

[With a Plate].

ON THE FOSSIL FLORA OF THE STAFFORDSHIRE COAL FIELDS.

[Witil a Plate].

BY

ROBERT KIDSTON, F.R.S.E., F.G.S.

E D I N B UR G H :

PUBLISHED BY ROBERT GRANT \& SON, 107 PRINCES STREET,

AND WILLIAMS \& NORGATE, 14 HENRIETTA STREET, COVENT GARDEN, LONDON. 



\section{I.IBRARY}

NEW YORK

BOIANICAL

G.SRDEN

V.-On Neuropteris plieata, Sternberg, and Neuropteris rectinervis, Kidston, n. sp. By Robert Kidston, F.R.S.E., F.G.S. (With a Plate.)

(Read 30th January 1888.)

Neuropteris plicata was deseribed by STEnNberg in 1826, from a spccimen from Miresehau, Bohemia, but the species seems to be very rare and imperfeetly known. As other ferns have been identified as $N$. plicate in error, I give a figure of what I believe to be Sterneferg's plant, an identification with which my friend M. Zeiller entirely agrees.

I also figure and deseribe a new specics of Neuropteris, which is identieal with that identified as $N$. plicata by RoenL, but from whieh species it is essentially distinet.

\section{Neuropteris plicata, Stcrnberg (figs. 1, 1a).}

Neuropteris plicata, Sternb., Vers., i. fasc. iv. p. 16 ; ii. p. 7 t, pl. xix. figs. 1 and 3.

Description.-Frond tripinnate (?), pinnæe alternate (?), linear-lanceolate; pinnules sessile, approximate or separated a short space, cordate-ovate or cordate-laneeolate, apex blunt, margin plieate; nervation very fine, central vein dividing into numerous branehes some distance below the apex; lateral veins numerous, curved upwards, and dividing three times. Terminal lobe elongate-triangular, small.

Remarks. - The only specimen of this speeies which has come under my notiee is that given on fig. 1. It was collected by Mr JoHN WARD, F.G.S., Longton, from whom I received it. It is in an exquisite state of preservation, and shows the nervation very beantifully. The veins are too close and too fine to be represented in a sketch of natural size (fig. 1), but a portion of a pinnule, enlarged four times to show the nervation, is given at fig. $1 a$. There are five of the ultimate divisions of the veins in $1 \mathrm{~mm}$. at the margin of the pimnule. The central vein appears to be formed rather by the united bases of the lateral veinlets than to consist of a mid-vein giving off lateral veinlets. The specimen I figure is identical in all respects with the type figure; and, when the two figures are compared, they bear a wouderful similarity.

Before seeing this example, I was inclined to regard $N$. plicatc as identical with N. flexuosa, ${ }^{*}$ being partly led to this belief by finding what I now regard as umlonbtedly N. flexuose identified as $N$. plicutat As Sternberg has omitted to give enlarged details of the nervation of his fern, its identification has been made much more difficult.

* Cutal. of Palcon. Plents, p. 94, where it is in error united witl Neur. Alesuosa. I however exclnded Neur. plicata from Nour. flexusa in my paper on the "Radstock Fossil Flora," Trans. Roy. Soc. Edin., vol, xxxiii. pt. ii. 1. 359.

+ Lesquereux, Coal Flore of Pennsyl., vol. i. p. 96, pl. x. figs. 1-4.

VOL. XXXV. PART 5. 
In addition to the type, two other pullished figures have been referred to $N$. plicate. These are the figures given by Lesquereux, which are elearly referable to $N$. flexuosa, Sternb., and those given by RoEHL, of which, probably both figures, but certainly one, is referable to my $N$. rectinervis, which is described below.

In $N$. flexuost, of which I have lately been able to examine many fine specimens from the Radstock Series, the terminal lobe is always very large, the pinnules more obtuse and not so lanceolate, and the lower auriele more pronounced than in N. plicata. The nervation in $N$. flexuose is also stronger and not so fine, there being usually at the margin of the pinuules only four veins in $1 \mathrm{~mm}$. Occasionally, however, in some specimens of $N$. Acxuosa, immediately within the margin of the pinmule, a fourth diehotomy of the reins takes place, which makes them more numerous than four in $1 \mathrm{~mm}$.

Locality.-Longton Iall Colliery, Longton, Staffordshire.

ILorizon:-Middle Coal Measures. From a bed about 2 feet above the Great Row Coal.

Neuropteris rectinervis, Kidston, n. sp. (figs. 2-4.)

Neuropteris plicata, Roehl (not Sternberg), Foss. Flora d. Steink.-Form. Westphalens, p. 38, pl. xiii. fig. \& (? pl. $x x$. fig. 7 ).

Description.-Pinnules sessile, alternate, oval or oblong, blunt, approximate or slightly separate, margin entire and free from plications; midrib very distinet, and extending almost to the apex; lateral veins distinet, numerous, fine, springing from the mid-rib with a gentle curve, and then running the greater part of their course at almost right angles to the margin of the pinnules, nsually once, but occasionally twice, divided. At the margin of the pinnules there are five to six ultimate divisions of the veins in $1 \mathrm{~mm}$. Terminal lobe oblong.

Remarks. - The specimens figured were collected in 1879 , but, from their fragmentary nature, have remained undescribed till now, when, in treating of $N$. plicata, it has been thought advisable to speeifieally distinguish this species, which has been confused with N. plicata, Sternb. I have the less hesitation in doing so, as the nervation is so characteristie, that $N$. rectinervis can at once be distinguished from all other species.

Of the two figures given by Roent as $N$. plicata, that on his pl. xiii. fig. 8 , is elearly $N$. rectinervis. About the other figure, given in his pl. $\mathrm{xx}$. fig. 7 , one eannot speak with so great certainty, thongh the probability is that it is also referable to N.rectinervis. He says, in deseribing the nervation of his specimens, "the lateral nerves stand almost upright to the principal nerve, are very distinct, elose together, once bifurcated, feebly bent"-which agrees entirely with the character of my plant.

The figures given show the variation in the size and form of the pimnules.

* Loc. cit., pl. $x$. figs. $1-4$.

† Foss. Flora. d. Steink.-Form. Westphalens, p. 38, pl. xiii. firg. 8; pl. xx. fig. 7 .

$\ddagger$ Loc. cit., 1. 38 . 
Locality.-Polton, Bonnyrigg, Mid-Lothian.

Ilorizon :-Lower Coal Measures.

FXPLANATION OF PLATE.

Fig. 1.-Neuropteris plicata, Sternberg. From shale above Great Row Coal, Longton Hall Collicry, Longton. Middle Coal Measures. (Collected by J. Warn, F.G.S.). Nat. size.

Fig. $1 \alpha$, Nervation $\times 4$.

Figs. 2-4.-Nentopteris rectinervis, Kidston, n. sp. From Polton, Bonnyrigg, Mid-Lothian. Lower Coal Measures. Nat. size.

Fig. $2 a$, Nervation $\times 4$. 
VI.-On the Fossil Flore of the Staffordslive Coal Fields. By Robert Kidston, F.R.S.E., F.G.S. (With a I'late.)

(Read 30th January 1888.)

PART I.

On the Fossil Plants collectede dorixg tife Sinking of the Shaft of the Hanistead) Colliery, Great Barr, near Birmixgitan.

The area comprised in the county of Stafford embraces five coal fields-

I. The Goldsitch Moss Coal Field, in the extreme north-east of the county.

II. The Cheadle and Chumet Valley Coal Field.

III. The Wetley and Shafferlong Coal Field.

IV. The Coal Field of the Potteries.

V. The South Staffordshive Coal Field.

The three first mentioned are of small extent, and as I know little of their fossil flora they are omitted from this series of papers on the Carboniferons Flora of the Staffordshire Coal Fields.

I, however, devote a separate communication to the fossil plants met with while sinking the shaft of the Hamstead Colliery, Great Barr, as a considerable part of the rocks passed through during this operation is clearly Upper Coal Measures, not Permian, as has been generally stated. The palæontological evidence, therefore, becomes of special importanee $\mathrm{m}$ determining the age of the red shales occurring in the upper part of this sinking, which have been usually mapped as Permian.

Stratil of the same age also occur in the Potteries Coal Field, but the fossil plants are not so fully known from them as from the strata passed through in the sinking at Hamstead. The determination, therefore, of the true position of the red shales at Hamstear assists one in dealing with the stratiography of other distriets of Staffordshire.

At the meeting of the British Association, held at Birmingham in 1886, Messrs Frederick G. Meacitem, MI.E., and H. Insley, read a paper, entitled "Notes on the Rocks between the Thick Coal and the Trias north of Birmingham and the Old South Staffordshire Coal Field;" this paper, of which an abstract is given in the Report of the British Association for 1886, ${ }^{*}$ contains the only published opinion, as far as $I$ am aware, that these red shales belong to the Upper. Coal Measures. 
Last year Mr Meachem kindly gave me the opportunity of examining the fossils collected during the sinking operations at Great Barr, and the Upper Coal Measure facies of many of the specimens is very pronounced. I revisited Hamstead Colliery this year, and went more carefully over the specimens. Mr Meacnen diligently collected examples of all the fossils met with during the sinking of the shaft, and at the same time noted at what deptlis they occurred, and the nature of the beds in which they were contained. The whole of this collection was most kindly placed at my disposal for determination and description. Mr F. G. Meachem has further favoured me with the details shown in the following scetion, which give the general character of all the beds from which the fossils were derived, as well as the thickness of the beds, and the depths at which they occur.

Tertical Section, showing the position of the Fossiliferous Strata passed through while sinking the Shaft of the Hamstead Colliery.

\begin{tabular}{|c|c|c|c|}
\hline $\begin{array}{l}\text { Depth from } \\
\text { Surface in } \\
\text { yards. }\end{array}$ & $\begin{array}{l}\text { Thickness of } \\
\text { Bed in yards. }\end{array}$ & Description of Bed. & Fossil Contents. \\
\hline $\begin{array}{l}\text { Surface to } \\
209 \text { yards. }\end{array}$ & $\cdots$ & $\begin{array}{l}\text { Red and brown sandstones, and } \\
\text { light red marls. }\end{array}$ & \\
\hline 209 & 2 & Light marl. & (?) Rachis of Fern. \\
\hline 243 & 34 & Red Marl. & Otontopteris Linulleyana, Stemb. \\
\hline 2671 & & Unconformity. & \\
\hline $336-346$ & 10 & $\begin{array}{l}\text { Red marls (4⿳亠丷厂 yards) and red } \\
\text { sandstone. Raindrop impres- } \\
\text { sions and desiccation cracks } \\
\text { occur at depth of } 336 \text { yards } \\
\text { in a blue band } 6 \text { inches thick. } \\
\text { The "Sprirortis" Limestone } \\
\text { occurs at a depth of } 341 \text { yards } \\
1 \text { foot, with a thickness of } \\
8 \text { inches. }\end{array}$ & 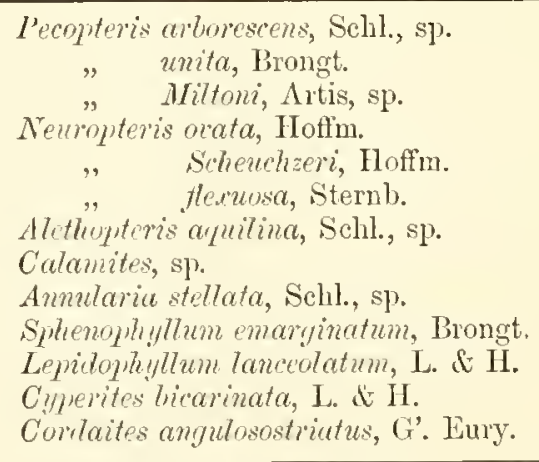 \\
\hline 350 & 13 & Brick-coloured marls. & Wulthia imbricata, Schimper. \\
\hline 400 & $5 \frac{1}{2}$ & Light purple rocky marl. & Nenropteris rarinervis, Lunbury. \\
\hline 411 & 3 & Purple and red shate. & $\begin{array}{l}\text { Calamites, sp. } \\
\text { Pecopteris Miltoni, Artis, sp. } \\
\text { Pecopteris, sp. } \\
\text { Neuropteris rarinervis, Bunbury. } \\
\text { Annularia stellata, Schl. } \\
\text { Cyperites bicarinata, L. \& II. } \\
\text { Lepidostrotns, sp. } \\
\text { Stigmaria ficoides, Sternb., sp. } \\
\text { "Talchia imlnicata, Schimper. }\end{array}$ \\
\hline
\end{tabular}


Ventricn Secrios-continued.

\begin{tabular}{|c|c|c|c|}
\hline $\begin{array}{l}\text { Wepth from } \\
\text { Surface in } \\
\text { yards. }\end{array}$ & $\begin{array}{l}\text { Thickness of } \\
\text { Bed in yards. }\end{array}$ & Deseription of Bed. & Fossil Contents. \\
\hline 440 & 24 & Red sandstone and grey shale. & 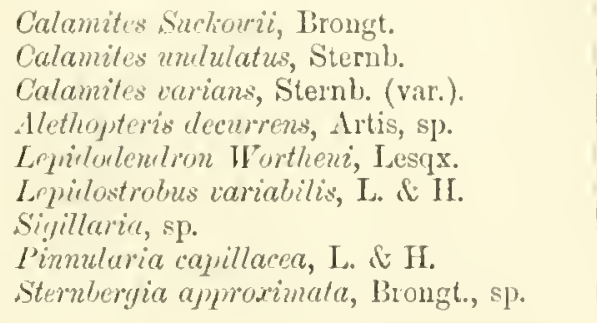 \\
\hline 451 & $\cdots$ & $\begin{array}{l}\text { Unconformity and erosion of } \\
\text { strata. Jleasures below this } \\
\text { assume a much purpler hue. }\end{array}$ & $\cdots$ \\
\hline $533-536$ & 3 & Blue bind. & 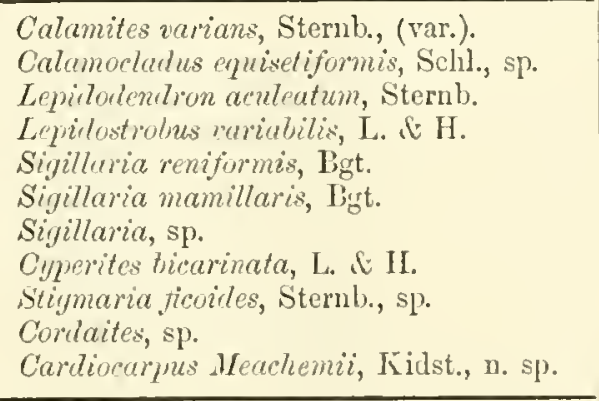 \\
\hline 550 & 1 & Grey shale. & $\begin{array}{l}\text { Carpolithus ovoideus, Göpp. \& Berger. } \\
\text { Etmondia mulis, M'Coy. }\end{array}$ \\
\hline 555 & $1 \frac{2}{3}$ & Dark grey elod, marine beds. & $\begin{array}{l}\text { Prorluctus semireticulalus, Martin. } \\
\qquad, \quad \text { scabriculus, Martin. } \\
\text { Eimonliu mulis, M'Coy. } \\
\text { Modiola lingualis, Phill. } \\
\text { Anthrucusia Urei, Flem. (= A. acuta), Sow. } \\
\text { Ledu attenuata, Flem. } \\
\text { Goniatites, sp., allied to G. evavatus, Phill. } \\
\text { Schizorlus, allied to S. carlumarius, Portl. }\end{array}$ \\
\hline 584 & 3 & Purple and grey shates. & $\begin{array}{l}\text { Calcmites Sucliouii, Brongt. } \\
\text { Neuropteris rarineris, Bunbury. } \\
\text { Mariopteris muricuta, Schl., var. nemosa } \\
\quad \text { (Brongt., sp.). }\end{array}$ \\
\hline 615 & $\cdots$ & $\begin{array}{l}\text { Top of "thick eoal." Shales } \\
\text { above it devoid of fossils. }\end{array}$ & $\cdots$ \\
\hline $623-625$ & 2 & $\begin{array}{l}\text { Shales with ironstones. A few } \\
\text { fossils, chielly Stigmaria. }\end{array}$ & $\cdots$ \\
\hline 631 & $\cdots$ & "Heathen coal." & $\cdots$ \\
\hline
\end{tabular}

The Fossil Plants ean be most conveniently considered in connection with their geological positions.

I. Those from the Upper Coal Measures, comprising the strata passed through from the surface to a depth of 451 yards. 
II. Those from the Hiddle Coal Measures, beginning at a depth of 451 yards, and comprising the remaining strata passed through.

\section{The Flora of the Upper Coal Measures.}

Calamites, Suckow.

Group I.-Cala mitin a, Weiss., Steinkohlen Calamarien, part ii. p. 59, 1884.

Calamitina (Calamites) varians, Sternb., var.

Calamites rarians, Sternb., V'ers, ii. p. 50, pl. xii.

Horizon:-At a depth of 440 yards.

Group III.-Stylocala mites, Weiss., ibid., p. 119.

Stylocalamites (Calamites) Suckowii, Brougt.

Calamites Suckowii, Brongt., Hist. d. végét. foss., p. 124, pl. xiv. fig. 6 ; pl. xv. figs. 1-6 ; pl. xvi. figs. 2-4 (fig. 1 ?).

Horizon:-At a depth of 440 yards.

\section{Stylocalamites (Calamites) undulatus, Sternb.}

Calamites undulatus, Sternb., Ters., i. fasc. 4, p. xxvi.; Ters., ii. p. 47, pl. i. fig. 2; pl. xx. fig. 8.

Calamites undulatus, Zeiller, Flore joss. du bassin houiller de Valenciemes, pl. liv. fig. 1, 1886.

Calamites undulatus, Brongt., Hist. de végét. foss., p. 137, pl. xvii. figs. 1-4.

Calamites Suchouri, var. undulatus, Weiss., Steinhohlen Calamarien, part ii. p. 135, pl. xvii. fig. 4, and text figure, p. 135,1884 .

Remarks.-This plant is regarded by several writers as a distinct species, but by others as a variety of Calamites Suckouri, Brongt.

Horizon:-At a depth of 440 yards.

\section{Calamites, sp.}

Remarks.-Several fragments, which, however, cannot be specifically determinet, vecur at deptlis of 336 and 411 yards respectively.

Annularia, Sternb.

Annularia stellata, Schloth., sp.

Casuarinites stellatus, Schloth., Flora d. Voruelt, p. 32, pl. i. fig. 4.

Annularia longifolia, Brongt., Prodrome, p. 156.

Asterophyllites equisetiformis, L. and 11. (not Schloth.), Fossil Flora, vol. ii. pl. cxxiv.

Fruit._Bruchmamia tuberculata, Sternb., Vers., i. fasc. 4, p. xxix. pl. xlv. fig. :

Horizons:-At depths of 336 and 411 yards. 


\section{Sphenophyllum, Brongt.}

\section{Sphenophyllum emarginatum, Brongt.}

Sphenophyllum cmarginatum, Brongt., Proctrome, p. 68.

Sphenophyllum emarginatum, Zeiller, Flora joss. du bassin houiller de Valenciennes, pl. lxiv. figs. 3-5, 1886.

IIorizon:-At a depth of 336 yards.

Neuropteris, Brongt.

Neuropteris rarinervis, Bunbury.

Neuropteris rarinertis, Bunbury, Quart. Jour. Geol. Soc, vol. iii. p. 425, pl. xxii.

Horizons:-At depths of 400 and 411 yards.

\section{Neuropteris ovata, Hoffim.}

Neuropteris ovata, Hoffmann, Keferstein's Teuchland geognostisch-geologisch daryestellt, rol. iv. p. I58, pl. iᄂ. figs. 5, 6, 7 (excl. fig. 8), 1826 .

Neuropteris nrata, Kidston, Trans. Roy. Soc. Edin., vol. xxxiii. p. 359, pl. xxii. fig. 1.*

Horison:-At a depth of 366 yards.

\section{Neuropteris Scheuchzeri, Hoffm.}

Neuropteris Scheuchzcri, Hoffm., Keferstein's Teucleland yeognostisch-geołogisch ilargestcllt, vol. iv. P. I58, pl. il. figs, 1-t, 1826.

Nowmoteris Schoucheri, Kidston, Trans. Roy. Soc. Etlin., vol. xxxiii. p. 356, pl. xxiii. figs. 1-2.**

Horizon :-At a depth of 336 yards.

\section{Neuropteris flexuosa, Stemb.}

Osmunda gigentea, var. $\beta$, Sternb., Vers., i. pp. 36 and 39 , pl. xxxii. fig. 2.

Nouropteris flexnosa, Sternb., Vers., i. fasc. iv. p. xvi.

Neuropteris' .texusea, Brongt., Itist. d. végét. foss., p. 239, pl. Ixviii. fig. 2 ; pl. lxv. figs. 2, 3.

Iorizon:- It a depth of 336 yards.

\section{Odontopteris, Brongt.}

\section{Odontopteris Lindleyana, Sternb.}

Odontopteris Linulleyana, Sternb., Yers., ii. p. 78.

Odontopteris obtusa, L. and H. (not Brongt.), Fossil Flora, vol. i. pl. xl.

IIorizon:- At the depth of 243 yards.

* Where remarks and further references will be found. 


\section{Pecopteris, Brongt.}

\section{Pecopteris arborescens, Schloth., sp.}

Filicites arborescens, Schloth., Flora t. Vorwelt, p. 41, pl. viii. figs. 13, 14.

Pecopteris arborescens, Brongt., Mist. a. végét. foss., p. 310, pls. cii. ciii., figs. 2, 3.

Pecopteris arborescens, liidston, Trans. Roy. Soc. Enlin., vol. xxxiii. p. 366.*

Morizon:-At a depth of 336 yards.

\section{Pecopteris unita, Brongt.}

Pecopteris unita, Brongt., Hist. d. végét. foss., p. 342, pl. cxvi. figss. 1-5.

Peropteris unita, Kidston, Trans. Roy. Soc. Eilin., vol. xxxiii. p. 367, pl. xxiv. figs. 2-9.*

Hori:on:-At a depth of 336 yards.

\section{Pecopteris Miltoni, Artis, sp.}

Fiticites Mittoni, Artis., Antedit. Phyt., pl. xiv.

Pecopteris Miltoni, Kidston, Trans. Roy. Soc. Edin., vol. xxxiii. p. 374.*

Pecopteris ablreviata, Brongt., Hist. d. végít. foss., p. 337, pl. exv. figs. 1-4.

Horizon:-At a depth of 336 yards.

\section{Alethopteris, Sternb.}

\section{Alethopteris decurrens, Artis, sp.}

Filicites clecurvens, Artis, Antenlit. Phyt., pl. xxi.

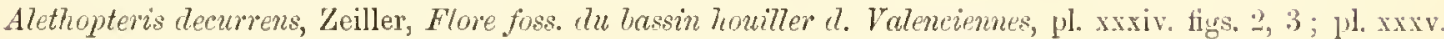
fig. 1 ; pl. xxxvi. figs. 3,4 .

Pecopteris heterophynla, L. and H., Foss. Flora, vol. i. pl. xxxviii.

Pecopteris Mantelli, Brongt., Irist. d. végét. foss., p. 278, pl. lxxxiii. figs. 3, 4.

Remarks. - This is most probably only a variety of Alethopteris lonehitice, schloth., sp., with which I have previously united it.

Horison:-At a depth of 440 yards.

\section{Alethopteris aquilina, Schloth., sp.}

Filicites aquilina, Schloth., Flora d. Vorwelt, p. 38 , pl. iv. fig. 7 ; pl. v. fig. 8.

Horizon:-At a depth of 336 yards.

* Where remarks and further references will be found. 
Lepidodendron, Sternb.

Lepidodendron Worthenii, Lesquerenx.

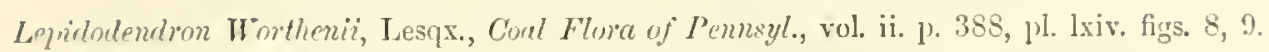
Lepidortendron Wonthenii, Zeiller, Flone fuss. du bassin houiller d. Yalenciennes, pl. Ixxi.

IIorizon:-At a depth of 440 yards.

Lepidophyllum, Brongt.

Lepidolphyllum lanceolatum, L. and H.

Lepidoqly flum Ianceolatum, L. and II., Fossit Flora, vol. i. 1]. vii. figs. 3, 4 .

Horizon:-At the depth of 336 yards.

Lepidostrobus, Brongt.

Lepidostrobus variabilis, L. and $H$.

Lepidostrolus varialitis, L. and H., Fossil Flora, vol. i. pls. x. xi.

IIorizon:- At a depth of 440 yards.

\section{Lepidostrobus, sp.}

IIori:on:-At a depth of 411 yards.

\section{Sigillaria, Brongt. \\ Sigillaria, sp.}

Horizon:-At a depth of 440 yards.

\section{Cyperites bicarinata, L. and $\mathrm{H}$.}

C!lperites bicainata, L. and II., Fossil Flora, vol. i. pl. xliii. figs. 1, 2.

Remark. - The grass-like leaves placed under Cyperites bicarinata are the foliage of Sigitlerio, and prohably also of some speeies of Lepidodendron.

These fossils, as far as I have been alle to obserre, have not two veins as supposed by LindeEy and Hutton. The little ledges formed by the two sides of a flat, central, single vein, form protected lodgments for the carbonaceous matter of the leaf, and often after the greater part of this substance has been remored from the other portions of the fossil. the prominence of these two lines of carbonaceous material, which frecunently coneeal the two edges of the mid-rib, have given rise to the erroneous opinion that the leaves contain two veins.*

* Lepidophyllum trinerve, L. and II., vol. ii. pl. clii.; Lopidophyllum binerve, Lebour; Illustrations of Fossil F'hents 1. 103, pl. lii., are subject to the same explanation. 


\section{Stigmaria, Brongt.}

\section{Stigmaria ficoides, Sternb., sp.}

Variolaria ficoides, Sternb., Vers., i. fasc. i. pp. 22, 24, pl. xii. figs. 1-3.

Stigmaria jicoùdes, Brongt., Class. cl. régét. foss., p. 28, pl. i. fig. 7.

Horizon:-At a deptls of 411 yards.

\section{Pinnularia, I. and H.}

\section{Pinnularia capillacea, L. and $\mathrm{H}$.}

Pinmularic capillacea, L. and H., Fossil Flora, vol, ii. pl. cxi.

Remarks.-Probably rootlets of various plants.

Horizon:-At a depth of 440 yards.

Cordaites, Unger.

\section{Cordaites angulosostriatus, Grand' Eury.}

Cordaites angulosostriatus, Grand' Eury, Flore Carbon. du Départ. de la Loire, p. 21i, pl. xix. Cordaites angulosostriatus, Zeiller, Végít. foss. d. terr. houill., p. 144, pl. clxxv. figs. 2, 3.

Horizon:-At a depth of 336 yards.

\section{Sternbergia, Artis.}

\section{Sternbergia approximata, Brongt.}

Sternbergia approximata, Brongt., Prodrome, p. 137.

Sternbergia approximata, L. and H., Fossil Flora, vol. iii. pls. ccxxiv.-ccxxv.

Remarks. - The fossils described as Stembergia (and Artisia) are casts of the pith cavity of stems of Cordaites.

Horizon:-At a depth of 440 yards.

\section{Walchia imbricata, Schimper. (Fig. 9.)}

Walchia imbricata, Schimper, Trait. d. paleúnt. végét., vol. ii. p. 239, pl. lxxiii. figs. 3, 3a, 3b.

Walchia imbricata, Tienault, Cours. a. botan. foss., Quatrième Anué, p. 85, pl. viii. figs. 7, 8, 1885.

Description.-Stem bearing closely placed distichous branches, patent, slightly curved. Stem leaves loosely imbrieated, linear, thick, incurved, blunt with a sharp point, keeled, about 1 centimetre long. Branch leares densely imbricated, slıort, subsquamiform, pointed-obtuse, thick, back distinctly keeled. 
Remarks. - Two specimens of this, the first true conifer I have met with in British Carboniferous rocks, have been found during the sinking of the shaft.

That figured comes from a bed of red marl at a depth of 350 yards from the surface; the other specimen is from a similar red bed, but at a depth of 411 yards.

Fig. 9 is taken from the first-mentioned specimen, and shows a number of lateral branches springing from the main stem. The leaves on the branchlets are tolerably well shown at various parts of the fossil, but the matin stem is indistinet, and does not show any foliage. The stem leaves of this speeies are figured by Schnper. Both braneh and stem leaves are distinctly keelcd from the presence of a prominent mid-rib.

The sccond example only shows a number of lateral branchlets, and is not so well preserved as that given at fig. 9.

Schexk * unites Walchia imbricata and $W$. flaccida, Göpp., to W. piniformis, Schloth., sp., as younger conditions of development. The same author also unites several other species of Walchice with $\mathbf{W}$. piniformis.

As there appears to be some difference of opinion as to the value of some of these specics, I provisionally adopt SchImper's name for the Hamstead plant, with whose figure and deseription it agrees in all respects.

Walchia is essentially a Permian genus, but on several oceasions W. piniformis, Schloth., sp., has been recorded from the Coal Measures.t Conversely, several species which attain their maximum development in the Coal Measures extend into the Permian formation. In fact, there is a much greater similarity between the flora of the Upper Coal Measurcs and that of the Permian than exists between that of the Upper and Lower Carboniferous Rocks.

In stating that this record of $W$. imbricate is the first occurrence of a coniferouts plant in the Carboniferons Rocks of Great Britain, it should be mentioned that there is now the strongest evidence to show that the stems previously supposed to be coniferous (Araucarioxylon) are cycadaceons. +

Horisons:-At depths of 350 and 411 yards.

\section{The Flora of the Middle Coal Measures.}

A very imperfect idea is afforded of the richness of the flora of the Middle Coal Measures, as developed in South Staffordshire, from the few specimens collected at Hamstead; but the meagre list of speeies recorded gives sufficient data for the comparison of the flora of the two divisions of the Coal Measures oceurring at Great Barr.

* Zittel's IIandbuch d. palcont., Band ii. Lief iii. p. 272, 1884.

+ Zeiller, Végét. foss. du terr. houil., p. 135; Geinitz, Iers. d. Stinkf. in Sachsen, p. 33.

¥ See Grand' Eury, Flore Curbon. du Départ. de le Loire, 1. 249, 1877; Schenk, in Zittel's Handbuch d. Palcont., Band ii. Lief iii. p. 213, 1881; Renault, Cours. d. botan. foss., 1881, p. 82. 
Calamites, Suckow.

Calamitina (Calamites) varians, Sternb.

Horizon:-At a depth of 533 yards.

Stylocalamites (Calamites) Suckowii, Brongt.

Horizon :-At a depth of 584 yards.

Calamocladus, Schimper.

Calamocladus equisetiformis, Sehloth., sp.

Casuarinites equisetiformis, Schlotl., Flora d. Forwelt, p. 30, pl. i. figs. 1, 2 ; pl. ii. fig. 3.

Calamocladus equisetiformis, Schimper, Traité $l$. paleónt. végét., vol. i. p. 324, pl. xxii. figs. I-3.

Hippurites longifolia, L. and H., Fossil Flora, vol. iii. pls. cxe., cxci.

Horicon:-At a depth of 533 yards.

Neuropteris, Brongt.

Neuropteris rarinervis, Bunbury.

Horizon:-At a depth of 584 yards.

Mariopteris, Zeiller.

Mariopteris muricata, Schloth., sp., var. nervosa.

Pecopteris nerrosa, Brongt., Hist. d. végét. foss., p. 297, pl. xciv.; pl. xcv. figs. 1, 2.

Pecopteris nervosa, L. and H., Fossil Flora, vol. ii. pl. xciv.

Horizon:-At a depth of 584 yards.

\section{Lepidodendron, Sternb.}

\section{Lepidodendron aculeatum, Sternb.}

Lepridodendron aculeatum, Sternb., Vers., i. fasc. i. pp. 20 and 23 , pl. vi. fig. 2 ; pl. viii. fig. 1l; fasc. ii., p. $25, \mathrm{pl}$. xiv. fig. $1-4$; fasc. iv. p. $x$.

Lepidodendron aculeatum, Zeiller, Flore foss. clu bassin houiller d. Valenciennes, pl. lxw.

Horizon:-At a depth of 533 yards. 
Lepidostrobus, Brongt.

Lepidostrobus variabilis, L. \& H.

Horizon :-At a depth of 533 yards.

\section{Sigillaria, Brongt.}

Sigillaria reniformis, Brongt., fig. 11.

Sigillavia reniformis, Brongt., Hist. 1. régét. foss., 1. 470, [1]. cxlii.

Sigillaria reniformis, Goldenberg., Ftora Sarcep. foss., Heft ii. p. 50, pl. viii. lig. 31.

Sigillaria reniformis, Sauveur, Végét. foss. de la belgique, pl. 1. fig. 1.

Sigillaria reniformis, Zeiller, Flore juss. d. bassin houiller de Valenciennes, pl. lxxxiv. figs. 1-6.

sigillaria cactiformis, Goldenberg, Flora Sarap. foss., 1Ieft i. p. 26, pl. iv, fig. 1.

Description.-Rilss wide, straight, smooth. Leaf scars reniform, approximate or distant, lateral angles distinct but not prominent. Vaseular eicatrieules; the two lateral lunate, central punctiform. Above the sear is oceasionally a small eicatricule, and between each sear is a transverse line. Decorticated stem longitudinally striate; cicatricules geminate, the two parts oval, united with each other or separate, varying much in shape with age.

Remarks.-The small specimen figured shows considerable difference in the size of the leaf scars and their relative distance apart. Towards the eentre of the specimen the leaf sears are smaller than those both above and below them, and the scars on the lower part of the specimen are much closer together than those at the top of the fossil.

From the peculiar eondition in which this specimen has been preserved, the subcortieal cicatricules are discernible through the bark, as distinetly defined oval elevations, which are visible in most of the leaf sears. One of these sears cnlarged at fig. 11" shows this clearly. Fig. $11 b$ gives the normal condition of the outer surface of the leaf sear, and is a reproduction of fig. $11 a$, with the subcortical cicatricules omitted. From this specimen is learnt the position held by the lateral cicatricules of the leaf sear to its germinate cicatricules of the decorticated stem.

Had any evidence been necessary to prove that the genus Syringodendron, Sternberg, was only a decorticated condition of Sigilleria, such evidence is afforded by the specimen now figured.

Sigillaria reniformis, Brongt., is easily distinguished from Sigillarice Sanvenri. Zciller, ${ }^{*}$ by the presence in the former speeies of a notch on the upper margin of the leaf scar, and the absence of the transverse wrinkling below the scars.

In regard to the function performed by these lateral lunate cieatrieules, as exhibited on the outer surface of the leaf scars, there is every reason to believe that they are the

* Zeiller, Flore foss. d. bassin honiller de Valenciennes, p. 559, pl. Lxxxiv. figs, 1-3. 
orifices of two secreting glands which are placed bencath the bark. These glands probably fulfilled their secreting function (whatever the nature of the sceretion may hase heen) after the fall of the leaf, and throughout the whole life of the plant, and consilering the great number of such glands on each plant of Sigillaria, Rexault throws ont the suggestion that perhaps it might be asked if the secretion from these glands does not form a large part of the inorganic matter found in coal."

The faint striations on the surface of the stem drawn at fig. 11 are eaused by the striations on the subepidermal surface, which lave been imparted to the outer surface by pressure.

Horizon:-In Blue Bind at a depth of 533 yards. ${ }^{\dagger}$

Sigillaria mamillaris, Brongt.

Fig. 10.

Sigillaria mamillaris, Brongt., Hist. d. végét. foss., p. 457, pl. cxlix. fig. 1 ; pl. clxiii. fig. 1 (rar. intermedia).

Sigillaria mamillaris, Goldenberg, Flora Sarap. foss., Heft ii. p. 32, pl. viii. figs. 6-8 (fig. 8, var. intermedia).

Sigitluria mamillaris, Weiss, Foss. Flora l. jüngst. Stk. u. d. Rothl., p. 164, pl. xv. figs. 1-4 (figs. 1, 2, var. abbreviata, fig. 4, var. elongata).

Sigillaria mamillaris, Zeiller, Flore foss. du bassin houiller de Valenciennes, pl. lxxxrii. fgss. 5-10.

Sigillaria pyriformis, Brongt., Hist. d. tégét. foss., p. 448, pl. cliii. figs. $3,4$.

Description.-Ribs straight or slightly flexuous, separated by a well-defined furrow: Leaf sears hexagonal or pyriform-liexagonal, as broad as long, or longer than broad, lateral angles distinct (especially in the forms with hexagonal leaf sears.) The surface, of the leaf scar is elevated from above downwards, so that the inferior margin stands at a higher level than the superior margin; the interfoliar portion of the ribs immediately below the leaf scar slopes domnwards, the leaf sear is thus placed on the upper slope of an elevated cushion. Taseular eicatrieule punctiform or slightly elongated transversely, lateral cieatricules lunate-elongate. Leaf scars somewhat close or more distant. The interfoliar portion of the cushion on which the leaf scars sit, bears two lines of transverse wrinkles, between which the wrinkles frequently extend, and thus cover the whole of the interfoliar portion of the cushion. Above the leaf sears is a well-defined arehed transverse furrow.

Cone sears, quadrate or irregular-triangular, with a central subeircular cicatrice, situated on the ribs, and forming a vertieil of several scries.

Decorticated stem striated longitudinally, and showing the three eicatrieules, the lateral cieatricules almost straight or occasionally lunate and united at their extremities, thus forming a cirele surrounding the vascular cicatricule.

* Renault, "Sur les cicatrices des Syringodendron," Comptes Rendus, 21th October 1887.

+ The lateral cicatricules in the leaf scars of Lepidodendron, Lepidophloios, and Bothrodendron, probably performerl the same function. When the structure of these lateral cicatricules is examined, they never show any trace of vascular tissue, but are filled with lax parenchyma. A good figure of their structure is given by Dr Felix (Untersuchungen j̈ber den Bau weslfälischer carbon Pflanzen, pl. ii. fig. $3 f$, König Preusseschen geol. Landesanslalt, 1886. 
Remarks.-Though the leaf sears of Sigillaric mamillaris are variable in the proportion of their length to their breadth, it is an extremely well-characterised species. 'The gradual eleration of the leaf scar from above downwards aflords a character by which it is distinguished from several liamed forms, some of which are, however, most probably Sigillaric mamilleris in a different state of preservation.

Of these may be specially mentioned Sigillaria pyriformis, Brongt., which does not appear to differ in any essential character, exeept that the leaf scars are horizontal with the surface of the ribs-a distinction arising in all likelihood from pressure. Sigillaria pyriformis is therefore united here with Sigillaria mamillaris.

Other very close allies are Sigillaria elliptica, Brongt., ${ }^{*}$ and Sigillaria notata, Steinhaner, sp. ${ }^{\dagger}$

This latter species differs chiefly in the leaf sears being of less width than the breadth of the ribs. Stennhauer's example came from the coal pits of Dunkerton, Somerset, which are now closed. I have, however, searched in Somerset for specimens of Sigilleric that conld be referred to Sig. notata, Steinhancr, in shales associated with coals on the same horizon as that from which the original specimens came, but without success.

The specimen of Sig. notata, figured by Brongriart, came from Anzin, near Valenciennes, $\neq$ and Boulay remarks $\$$ "Brongriart indicates this species from Anzin. I have collected very well-characterised specimens of it at the pit of Petitc-Sorcière, near Jemmapes (Belgim). This plant, which Brovgriart regarded as allied to Sigillaria elliptice, is more closely allied to Sigillaria mamillaris, of which it might well be only a condition or a fragment."

The question whether Sig. elliptica, Brongt., and Sig. notata, Stcinhaner, sp., are only forms of $S$. mamillaris, or individual species, must therefore in the meantime remain open.

Horizon:-In Blne Bind, at a depth of 533 yards.

\section{Sigillaria, sp.}

Horizon:-At a depth of 533 yards.

\section{Cyperites bicarinata, L. and H.}

IIorizon:-At a depth of 533 yards.

Stigmaria, Brongt.

\section{Stigmaria ficoides, Sternb., sp.}

Horizon:-At a depth of 533 yards.

* Brongt., Hist. d. végét. foss., p. 447, pl. clii. figs. 1, 2 ; pl. clxiii. fig. 4.

+ Steinhauer, Truns. A mer. Phil. Soc., 1818, p. 294, pl. rii. fig. 3 (Phytolithus notatus).

\pm Brongt., Hist. d. végét. foss., p. 449, pl. cliii. figg. 1.

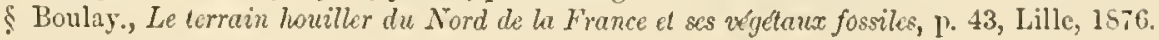




\section{Cordaites, Unger.}

Cordaites, sp.

Horizon:-At a depth of 533 yards.

Cardiocarpus, Brongt.

Cardiocarpus Meachemii, Kidston, 11. sp., figs. 5-7.

Description.- Seed cordate, about $13 \mathrm{~mm}$. broad, $13 \mathrm{~mm}$. long, base emarginate, apex acute. Nucule cordate, central, with a medial line extending from the base to the apex. Wing about $4 \mathrm{~mm}$. broad.

Remarks. - Several of these little seeds are given on figs. 5-7. That at fig. 5a shows the outline of the seed, but the form of the mucule is not elearly defined; this deficiency is supplied by the isolated mucule given at fig. 7. The margin of the specimen shown at fig. 6 is not distinctly exhibited in the fossil, but there is an indication of a line surrounding the nuenle, about halfway between the nucule and the margin of the wing. The apparent emarginate apex of fig. $5 b$ is the result of an accidental splitting of the testa.

Cardiocarpus Mcachemii is closely allied to the Cardiocarpus figured by FeIsTManteL as C. emarginatum, Göpp. and Berger (not Brongt.),* and differs only in its smaller size. My chief reason, therefore, for applying a new name to the Hamstead seeds is the eireumstance that there is little evidence to show that the specinens figured by FEIsTMANTEL are similar to the Cardiocarpum emarginatum, Göpp and Berger t-in fact, from the imperfect nature of the fignres given by these authors, it seems impossible to arrive at what are the true characters of their species.

Should Feistanantel's specimens eventually prove to be specifically similar to my Cardiocarpus Meachemii, his fossils might be distinguished as var. major.

I have pleasure in naming this seed after Mr F. G. Meachem.

Horizon:-In Blue Bind, at a depth of 533 yards.

\section{Carpolithus, Sternb. \\ Carpolithus ovoideus, Göpp. and Berger, sp.}

Fig. 8.

Rhablocarpus (?) ovoideus, Weiss, Foss. Flora d. jüngst. Stl. u. d. Rothl., p. 206, pl. xvii. fig. 4 ; j!. xviii. figs. $10-14,18-21$.

Rhabdocarpus ovoideus, Güpp. and Berger, De fructitus et seminibus, p. 22, pl. i. fig. 17.

Rhablocarqus ovondeus, Gojpert, Foss. Flora d. Perm. Form., p. 173, pl. xxvii. figs. 9, 10.

Rlabdocarpus Germaviamas, Göppert, Foss. Flora d. Perm. Form., p. 270, pl. lxiv. fig. 14.

Carpolithus memlirunaceus, Göpp. and Berger, De fructibus et sminitus, p. 25, pl. ii. figs. 19, 20.

Carpolitlus membranacen, Göppert, Foss. Flora d. Perm. Form., 1. 178, pl. xxix. figs. 19-21.

(?) Curpolites ellipticus, Sternb., Vers., i. fasc. 4, p. xl. pl. vii. fig. 1.

(?) Carpolites regularis, Sterub., Vers., i. fasc. 4, p. xl. pl. vii. fig. 2.

* Vers. d. Bohmischen Kohlenablagerungen, Abeth. ii. p. 46, pl. xx. figs. 4-6.

† Gopp. and Berger, De fructibus et seminibns, p. 24, pl. iii. figr. 35. 
Description.-Small oval or elliptieal seeds, sometimes almost circular from pressure acting in the direction of their axis; one or both extremities rounded, or more or less pointed. Secds bracteate, sessile, bolne in two opposite alternate rows on a spike-like axis.

Remarks. - The form of these little seeds much depends on the direction in which pressure has acted upon them. When flattened with pressure acting at right angles to their axis, they are usually elliptical and pointed, as at fig. $8 b, 8 d$; but when pressure acts on the apex or base of the seed, they are more or less cireular, as at $8 c$. Between these two extremes are intermediate forms. The surface of the seeds generally shows foldings of the testa, and in some cases the seeds appear to have a narrow surrounding border: but this appearance is also due to pressure.

Horizon:- Many specimens on the surface of a small slab, of which fig. 8 gives foul examples, from a depth of 550 yards.

\section{General Remarks.}

From an examination of the foregoing lists, it will be seen that a proportion of the species recorded are common to both horizons.

Ammularia stellata, Sphenophyllum emarginatum, Neuropteris ovata, Neuropteris Scheuchzeri, Neuropteris flexuosa, Odontopteris Lindleyana, Pecopteris arborescens, Pecopteris unita, Lepidodendron Worthemie, Cordaites angulosostriatus, and Walchia imbricete are, however, specially characteristic of British Upper Coal Neasure rocks, though a few of these species have been observed in the Middle Coal Neasures, but there they are much more scarce.

The Middle Coal Measure facies of the flora, collected from the strata of that horizon at Hamstead, is more characterised by the absence of Upper Coal Measure species than by the ocemrence of species restricted to the Middle Coal Measures. Sigillaria mamillaris is, however, a specially characteristic Middle Coal Measure plant.

On the publication of lists of the fossil flora of the South Staftordshire Middle Coal Measures, the peculiar characteristics of the Middle Coal Measure flora will be much more distinctly seen.

In comparing the list of fossils from the Upper Coal Neasures of Hamstead with those of the Upper Coal Mleasures of the Radstock and Firrington series of the Somerset Coal Field, one cannot fail to be struck with the great similarity of their fossil contents. All those found at Hamstead, with the exception of Calamites undulatus (which may be only a form of C. Suckowiz), Alethopteris decurrens (which is, perhaps, a variety of $A$. lonchitica that occurs at Radstock), Lepidophlyllum lanceolatum, and Lepidostrobus variabitis,--all occur in the Radstock series, and the greater part of the species also occur in the Farrington series. From the Red Shales which separate the Radstock and Farrington Series I have seen few vegetable remains, 
but, as the Hamstead plants are found both below and above these Radstock red shales, it is clear that they existed during the deposition of these beds: and further, the few fossils which I have seen from them are similar to those of the Radstock and Farrington series, I therefore conclude that the Upper Coal Measure red shales that ovcrlie the Middle Coal Measures at Hamstead are a northern extension of the red shales which form such a well-marked horizon over a considerable portion of the Somerset Coal Field.

The Nollusean remains, for whose identifieation I am indebted to $\mathrm{Mr}$ ЈоHN Youvg, F.G.S., are of considerable interest, and bring forcibly forward some points in their vertieal distribution which do not appear to have received the attention they deserve.

Mr Meachem informed me that, through an aceident happening to the collection, a number of the specimens of shells were completely destroyed, and among these was a Euomphalus. The speeies cxamined and identified do not, therefore, represent the whole fauna collected, but only those that are still preserved.

The Mollusea identified are-

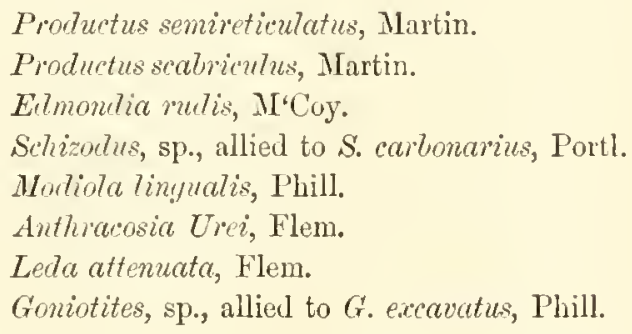

Learing out of consideration those individuals which are only generieally identified, two of the species, Modiola linguatis and Leda attemuata, have been reeorded from the upper beds of the Calciferous Sandstone series.* P. semireticulatus, P. scabriculus, and Edmondia mudis are frequent in the Carboniferous Limestone series of Scotland, while Anthracosia Urei is usually restricted to the Lower Coal Micasures.

Any one, judging of the age of the roelis from the Molluscan remains, would, without doubt, elass them as Lower Carboniferous, whereas they are undoubtedly of Upper Coal Measure age.

This case is not an isolated one, and Mr. JoHn Young has referred to such oceurrenees in his paper entitled "Notes on the Occurrence and Range of Lingula in the Carboniferous Scries of the West of Scotland." $\dagger$ Speaking of the apparent extinction and reappearance of an organism in a ligher horizon, the paper coneludes with the following remark:- "Of such changes we have evidence in several of our coal seams, formed of the remains of a terrestrial vegetation accumulated in swamps at or near the sea level, and now found to lie overlaid by a great thiekness of fossiliferous marine strata. But

* Mem. Geol. Survey of Scotland, Explan. to sheet 23, Lanarkshire Central District, p. 57.

+ Trans. Geol. Soc. of Ghesgow, vol. ii. p. 144. 
wherever we find a sudlen extinction of the organie life in any stratum, we ale not to suppose that such extinction was universal. In most cases it must have heen conparatively loeal, for a total extinction would imply a new ereation of the same forms in every succeeding stage of strata in which they are met. The most probalble supposition is, that during all the long geological ages in which our fossiliferous strata were heing deposited, or from the first appearance of life on onr globe, there never has been, at any one time, a total extinction of the flora or famma from the remote period till the present time; and when we find in our Coal Measures the constant reappearance of certain wellknown species after each local extinction, in higher and bigher stages of strata in the same locality, we are naturally led to conclude that, while they become extinct over these tracts, they must have continued flourishing in other parts of our Carboniferous sea, and that they spread from these spots into their old loealities wherever the condition of the sea-bottom again became favourable to their growth and development." In a letter, dated October 26, 1887, he further says:- "There can be no doubt of the repeated occurrence in higher and higher horizons of many of the marine and fresh water forms of life found in our Seottish Coal Measures. Since this paper (that quoted above) was printed, I have been able to trace other forms besides Lingula, that range from the very lowest fossiliferous marine beds up into that of the Permian Formation. It is, therefore, quite unsafe to take any one organism as tharacteristic of any special horizon, for closer investigation of the strata in any country is constantly proving their recurrence or oecurrence in higher or lower beds."

Now, with organisms possessed with the property of locomotion, this is quite what may be expected. As the conditions became unfarourable for their growth and existence, they would remove to more suitable situations. Of course, conditions may arise which are unfarourable to the life of organisms that previously flourished in a given locality; and should no favourable conditions arise or exist within suitable distances for migration, there would be a total local extinction of species, which, perhaps, might extend over large areas, but that such occurrenees were not miversal is evidenced by the repeated recurrence of species in higher and higher zones, separated by grcat masses of stratir destitute of their remains.

In regard to plants the case is different. They being fixed to the localities in which they grow, are of necessity obliged to suceumb shonld any subsidence or unfavouratile condition for their growth arise, and did the conditions again become farourable, deseendants from the original individuals could never more return.

Of course, similar species were no doubt flourishing in other localities, and when the subsided area had again been clevated into elry land, it night have becn peopled with new individuals of the same species, and it is true that certain species again revisit the old haunts of their kindred, but it is only comparatively few thist ever do so, and with them they always bring new associates. Thus the change in the flora gradnally progresses.

It is also true that there are vast masses of rock that show little change in their flori, TOL, XXXV, PART 6. 
but these are succeeded by rocks in which many of the old species have disappeared and new species take their place by the side of the survivor's.

'This state of matters maintains throughout the whole of the Coal Measures, and further there does not seem to be the same complete disappearance, and then after a time a reappearance of the same old forms, as in the case of the Mollusea, but instead, a constant gradual change. 'This gradnal change is, however', so marked, that it leaves a most sure and certain stamp for the recognition of the comparative age of the rocks in which the fossils oceur. This leads me to believe, and every alditional experience confirms this opinion, that for the classification and correlation of the rocks of the Carboniferous Formation, the evidence derived from plants is more reliably conclusive, and less liable to variation, than that delived from animal remains.

While speaking on this subject I might add further, that from the base of the Carboniferous Formation to the base of the Millstone Grit, the flora has a facies peculiar to that period, and of the many species of plants ocemring in Lower Carboniferous rocks in Britain, it is very doubtful if any species pass into or above the Millstone Grit. I have seen slight evidence to think there may be one exception, but as far as I at present know, only one.*

From the Millstone Grit, though the difference of the flora is suftieiently elearly defined to admit of a satisfactory threefold division of the Coal Measures, there is no such sudden break as occurs between the Lower and Upper Carboniferous, nor does a sudden break take place even at the top of the Upper Coal Measures, for several of the Upper Coal Measure plants pass into the Permian Formation.

For the ficilities I have had given me for examining and describing the Hamstead fossils, my thanks are due to MI J. MeAchem, Manager of the Hamstead Colliery, and especially are they due to Mr Fred. G. MEAchem, by whom the records of the sinking were kept, and from whom I have received the particulars contained in the seetion given on pp. 318-19. 1 am also indebted for assistance to Mr H. Inscer, Ashton.

It is to be hoped that all who have similar facilities for collecting the fossils met with in Pit Sinkings and other mining operations, will avail themselves of these opportunities, as such collections as that made at the Hamstead Colliery, where the horizon of each specimen has been carefully noted, are of the ntmost importance in working out British Palaontology.

* I exclude Stigmaria, which is the root of several Lycopods, and as none of the Lower Carboniferouts Lycopods pass into or above the IIillstone Grit as far as I know, Stigmaric, being the root of any one of these Lycolorls (Lepidodendron, Sigillaria, Lepidophloios) cannot be regarded as a true, individual species, and though these Lower Carboniferous Stigmaria are individually undistinguishable from the Stignaria of the Upper Carboniferons, they cannot be regarded as specifically the sanc. 


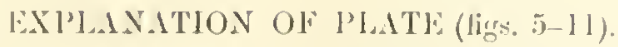

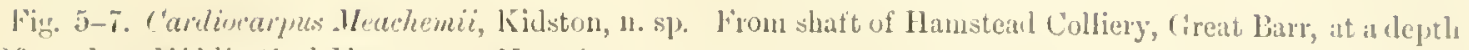
of 536 yards. Midelle Coal Mleasures. Nat. size.

Fig. s. Carpolitleus ovideus, Ginpp. and Berger. From shaft of Famstead Culliery, Great limr, at al depth of 5.50 yards. Middle Coal Measures. Nat. size.

Higr. 9. Walchice imbrimla, Sehimper. From shaft of Hamstead Colliery, Great ljarr, at a deptle of 3ju yards. Upper: Coal Heasures. Nat. size.

Fig. 10. Sigillaria mamillaris, Brongniart. Firom shaft of llamstead Colliery, Great liarl, at at depth of $5.3: 3$ yads. Mildle Coal Ileasures. Xat. size. 10", Leaf scar $\times 2$.

Fig. 11. Sienilluria reniformis, Brongniart. From shaft of IIamstead Colliery, Great Liar', at a lepth of 533 yarls. Middle Coal Measures. Nat. size. 11a, 11/, Leaf scars $\times 2$. 
, 

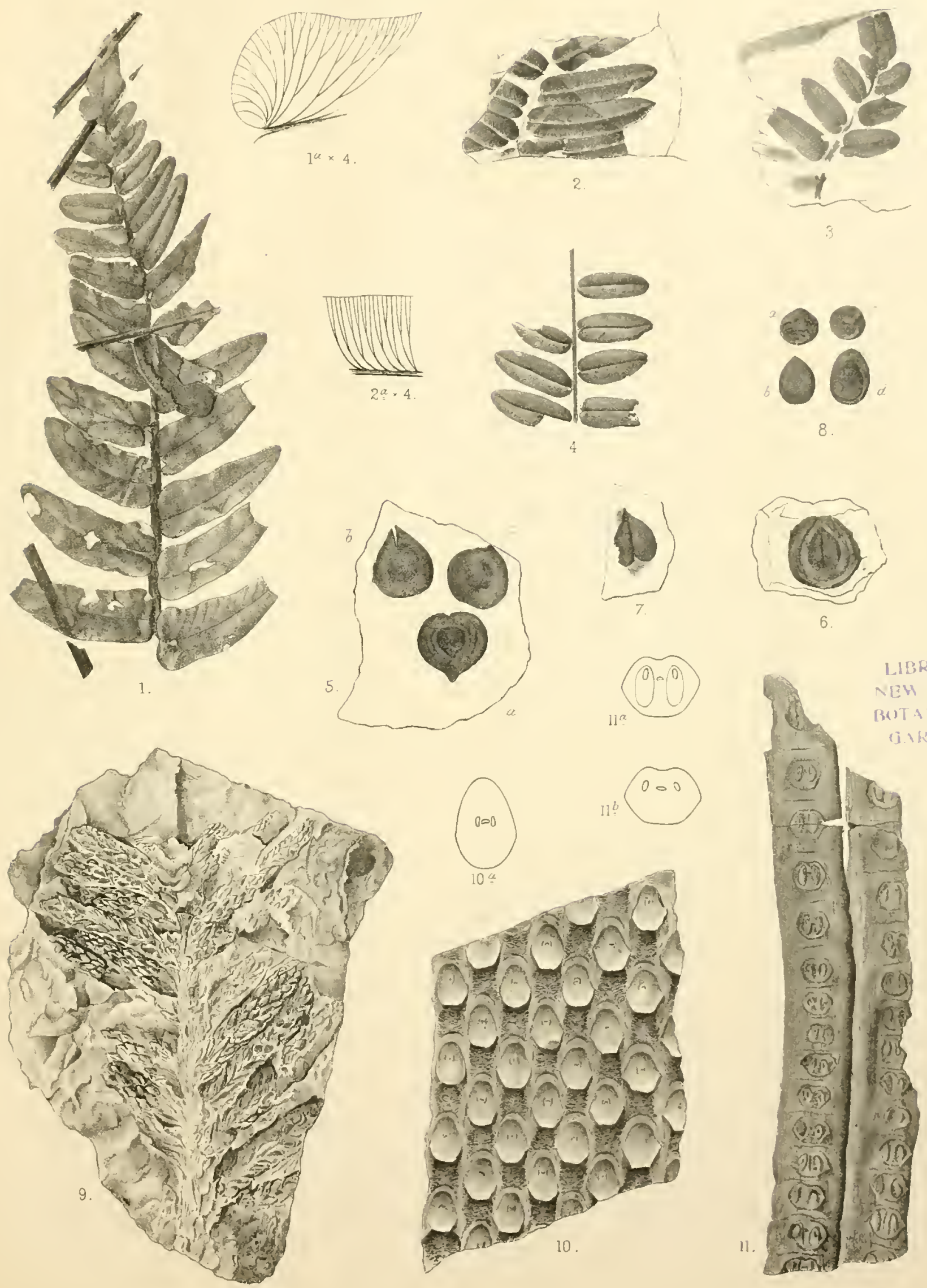

Fis. 1. Neur. Plicata, Sternb. 2-4, NeUr. ReCtinervis, Kidston $n s$.

5-7. Cardiocarpus Meachemil, fidstom, $n$ s

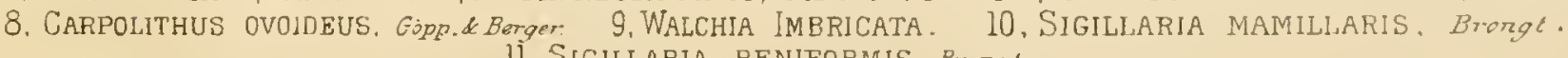
11. Sigillaria RENIFORMis, Brongt. 


OE919 K443

Kidslo Robet

$\left.||_{3}^{1}\right|_{5}||_{185}$

1111

gen

111 


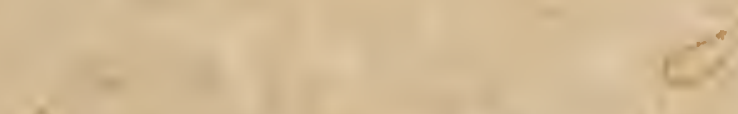

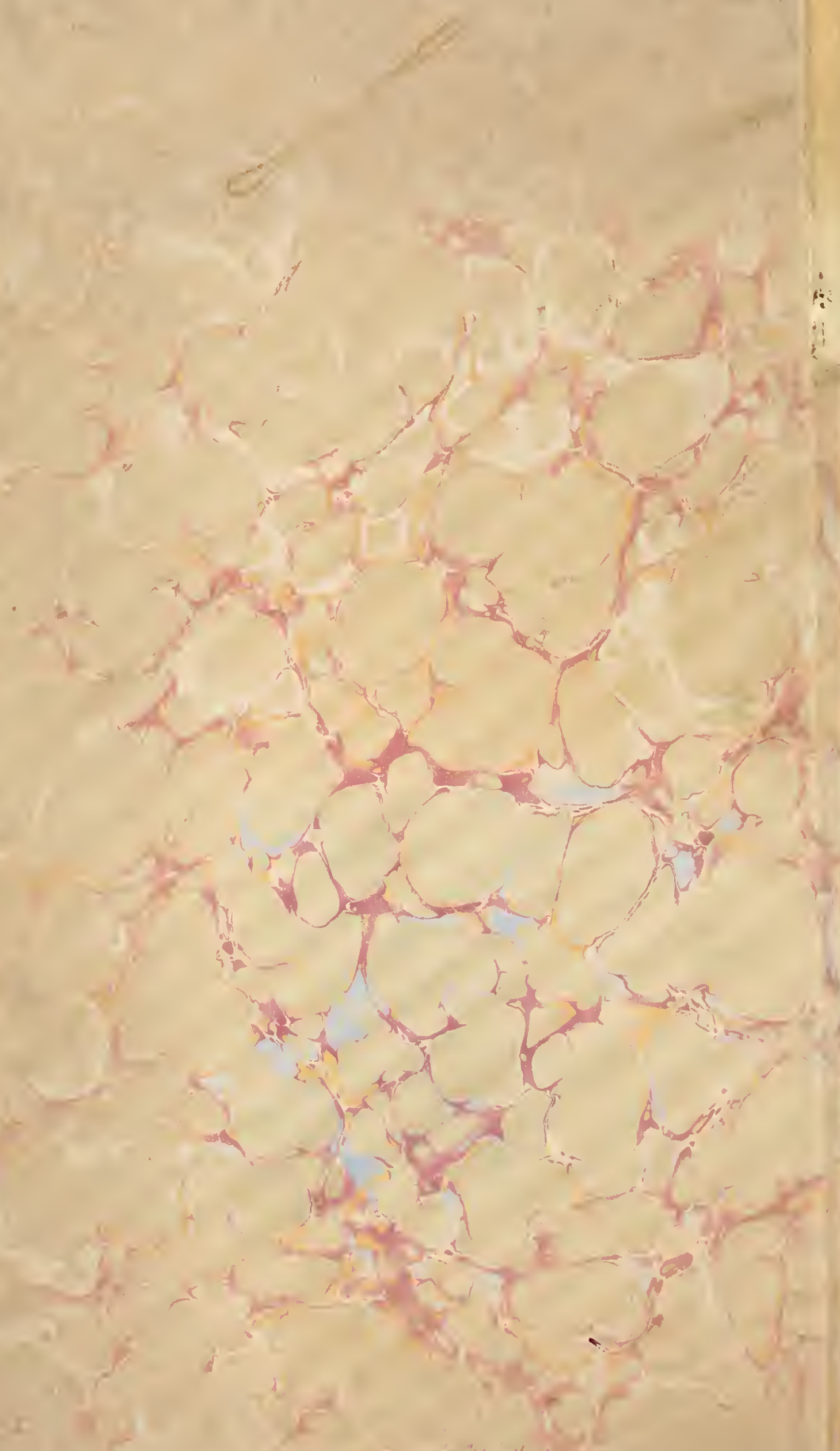

